\title{
Politik Kiai Dan Resistensi Sosial
}

\author{
Vellayati Hajad \\ Email: Vellayati.hajad@gmail.com
}

\begin{abstract}
Today many emerging Kiai who play outside the Pesantren and leaving its main task as an educator in Islamic education institutions and engage in practical politics. The actions taken by Kiai (whatever it is) will lead to a variety of social and political implications are very interesting to examine scientifically. Furthermore, this writing tried to describe an important finding that Kiai involvement in politics, even though on the one hand advantageous for Kiai and the pesantren, but on the other hand decrease the legitimacy of Kiai and bring resistance of society.
\end{abstract}

Keywords: Kiai, Political, Social, Resistant

\section{Abstrak}

Saat ini banyak bermunculan Kiai yang bermain di luar Pesantren dan meninggalkan tugas utamanya sebagai pendidik di lembaga pendidikan Islam dan terlibat dalam politik praktis . Tindakan yang diambil oleh Kiai ( apapun itu ) akan menyebabkan berbagai implikasi sosial dan politik yang sangat menarik untuk memeriksa secara ilmiah. Selanjutnya, tulisan ini mencoba untuk menggambarkan suatu temuan penting bahwa keterlibatan Kiai dalam politik, meskipun di satu sisi menguntungkan bagi Kiai dan pesantren, namun di sisi lain mengurangi legitimasi Kiai dan membawa resistensi dari masyarakat .

Kata Kunci: Kiai, Politik, Sosial, Tahan

\section{Pendahuluan}

Meskipun telah banyak peneliti yang menjadikan Kiai sebagai objek kajian, namun selalu saja tersedia perspektif tertentu yang belum bisa diungkap. Hal ini menunjukkan bahwa Kiai memiliki beragam sisi yang dapat diteliti dari berbagai aspek keilmuan. Dan akhirnya, posisi Kiai yang seperti itu, mempertegas kedudukan Kiai yang sangat sentral dalam kehidupan masyarakat dan juga telah menjadi entitas politik yang berpengaruh di Indonesia. Perdebatan tentang keterlibatan Kiai dalam politik selalu berada dalam dua kutup pendapat yang kontradiktif. Keberlawanan tersebut dapat dilihat dari pendapat yang mengabsahkan dan menganggap keterlibatan Kiai dalam politik adalah sebagai sesuatu yang wajar, serta disisi lain muncul pendapat yang mengkritiknya dan memandang keterlibatan Kiai dalam politik sebagai pengingkaran terhadap nya, yaitu menjadi pendidik dan pengasuh pondok pesantren yang seharusnya selalu menjaga independensi dan posisi dari partai politik. 
Pendapat yang pertama, mengasumsikan bahwa Kiai, bagaimanapun juga merupakan entitas yang memiliki hak dan aspirasi politik sebagaimana warga negara lainnya. Hal ini didukung oleh argumentasi teologis yang membernakan pilihan politik praktis. Pendapat ini semakin kukuh apalagi didukung oleh realitas semakin banyaknya Kiai yang terjun dalam dunia politik langsung maupun tidak. Pendapat kedua mengkritik dengan keras keterlibatan Kiai dalam dunia politik sebagai hal yang lebih banyak bahaya daripada manfaatnya (Khoirudin, 2005; ix-x). Hal ini mengacu pada realitas politik kekinian yang sering dianggap "kotor", maka keterlibatan Kiai dalam dunia politik bagaimanapun baik dan kokohnya landasan serta argumentasi teologisnya, akan ikut terseret kedalam dunia yang "kotor" pula. Perdebatan seperti ini memang tidak akan pernah selesai, sebab masing-masing akan menunjukkan berbagai argumentasi etis maupun praksis untuk mendukung pendapatnya.

Di dalam tulisan ini kedua pendapat tersebut akan diletakkan sebagai dasar pijak untuk mencermati lebih jauh bagaimana praktik politik Kiai dan menganalisis implikasinya secara berimbang, baik terhadap eksistensi Kiai maupun terhadap komunitas pesantren. Untuk kepentingan analisis tulisan ini mengambil contoh praktik politik di Pondok Pesantren Al-Munawwir Krapyak Yogyakarta.

\section{Metode Penelitian}

Metode dalam penelitian ini merupakan jenis penelitian case study yang melihat bias politik Kiai: pragmatisme yang berujung resistensi sosial studi kasus pada Kiai Pondok Pesantren Krapyak Yogyakarta. Metode pengumpulan data dalam penelitian ini adalah interview mendalam serta didukung oleh data sekunder terkait fokus dalam penelitian ini. Metode analisis data pada penelitian ini deskriptif analisis terhadap hasil temuan lapangan yang diperoleh berdasarkan hasil wawancara, yang kemudian di perkuat dengan data-data sekunder yang terkait dengan kajian tersebut untuk kemudian ditarik sebuah kesimpulan.

\section{Kerangka Teoritis}

Kiai dapat dikatakan sebagai pemimpin politik. Sebagai seorang pemimpin politik Kiai berusaha memelihara kekuasaanya dengan berbagai cara. Bila raja berusaha mempertahankan kekuasaan dengan memperkuat barisan militer dan birokrasi maka Kiai memelihara posisinya dengan aktivitas religius. Stabilitas kepemimpinan Kiai amat tergantung pada loyalitas para pengikutnya dan hubungan Kiai dengan Kiai lain yang 
berpengaruh. Dengan demikian, Kiai harus membangun jaringan dengan pengikutnya dan juga dengan sesama Kiai.

Jaringan yang dibangun bisa dengan dua cara, yaitu horizontal dan vertikal. Jaringan horizontal adalah hubungan yang dibangun Kiai dengan keluarga dan sahabatnya sesama kalangan yang menuntut ilmu agama. Dari mereka, Kiai mendapat dukungan baik moril maupun materil. Jaringan vertikal adalah hubungan yang dibangun Kiai dengan guru-gurunya dan pengikutnya. Dari guru-gurunya, selain mendapat ilmu Kiai juga mendapat akses kekuasaan berupa jaringan hubungan dengan keluarga dan sahabat gurunya. Semua hal tersebut menunjang proses seorang Kiai dalam memperbesar pengaruhnya dalam masyarakat. Dari pengikutnya, Kiai mendapat banyak hal, seperti materil. Pengikut Kiai memasok imbalan materi dalam bentuk sumbangan, wakaf tanah, dan bantuan tenaga kerja. Dari segi non-materil mereka adalah orang-orang yang dapat diandalkan untuk menggalang massa. Tidak mengherankan bila dengan semua jaringan dan dukungan yang didapat dari mereka, Kiai leluasa bergerak dalam partai politik dari dulu hingga sekarang.

Kalangan yang termasuk sebagai pengikut Kiai adalah santri. Bagi seorang santri, Kiai adalah figur sentral sumber untuk mendapatkan ilmu. Dalam proses belajar-mengajar di pondok pesantren, posisi Kiai amat sentralistik sehingga santri memahami teks sebagaimana Kiai memahaminya. Bahkan dalam hal tertentu, Kiai tidak hanya bertindak sebagai guru, kia juga adalah orang tua bahkan Kiai lebih tinggi kedudukannya disbanding orang tua, hal ini tidak mengherankan karena Kiai seringkali membiayai kelangsungan hidup santri melalui dana pribadinya. Itu lah sebabnya, hubungan anatar santri dan Kiai bisa berlangsung seumur hidup atau bahkan dalam 7 turunan. ( Iik Arifin : 1990 )

\section{Struktur Dan Pola Kekuasaan Kiai dalam Lingkungan Pesantren}

Di tengah perkembangan masyarakat Indonesia pada umumnya dapat dijumpai beberapa gelar sebutan yang diperuntukan bagi ulama (Kiai), misalnya di daerah Jawa Barat (Sunda) orang menyebutnya ajengan, di daerah Aceh dikenal dengan 'Teungku', di daerah Sumatera Barat biasa disebur 'Buya', di Makasar biasa disebut 'Tofranrita', di daerah Madura disebut 'Nun' atau 'Bendara' yang biasa disingkat ' $r a$ ', di Lombok dan sekitarnya biasa dipanggil 'Tuan Guru'. Khususnya di Jawa sebutan Kiai biasa disamakan dengan sunan ataupun 'susuhan. 
Dari sudut fungsinya, Kiai pada masyarakat Jawa terbagi kedalam dua kategori, yaitu: pertama, kelompok Kiai yang berada pada jalur dakwah dan pendidikan (al-dakwah wa altarbiyah). Kelompok ini biasanya disebut Kiai pesantren atau ulama pondok pesantren, dengan tugas utamanya sebagai guru dan pengajar sekaligus mubaliq (penyiar) agama. Kedua, Kiai yang menduduki suatu jabatan dalam pemerintah yang biasa disebut sebagai penghulu, yaitu mereka yang aktivitas sosial keagamaannya sebagai pelaksana dalam bidang kehakiman yang menyangkut hukum (syariat) Islam.

Intensitas Kiai memperlihatkan peran yang otoriter disebabkan karena Kiai adalah sang perintis, pendiri, pengelola, pengasuh, pemimpin dan bahkan juga pemilik tunggal pesantren. Keberadaan Kiai dalam pesantren sangat sentral sekali, dan pada tingkat tertentu kemajuan dan perkembangan pesantren tergantung pada Kiai. Dengan demikian, kemajuan dan kemunduran pondok pesantren benar-benar terletak pada kemampuan Kiai dalam mengatur operasionalisasi dan pelaksanaan proses belajar mengajar di pesantren, sebab Kiai merupakan penguasa baik dalam pengertian fisik maupun non fisik yang bertanggung jawab atas kemajuan pesantren. Dalam konteks ini, kepemimpin Kiai yang kharismatik di kalangan pondok pesantren didasarkan pada kualitas 'luar biasa'. Kata luar biasa dalam hal ini merupakan pengertian yang sangat teologis karena untuk mengidentifikasi daya tarik pribadi yang melekat pada diri seorang kyai diasumsikan bahwa ia memperoleh kekuatan tersendiri dari Sang Maha Pencipta.

Kedudukan Kiai di pondok pesantren adalah sebagai pemimpin tunggal, memiliki otoritas tinggi dalam menyebarkan dan mengajarkan pengetahuan agama Islam.Tidak ada figur lain yang dapat menandingi kekuasaan Kiai kecuali figur Kiai yang lebih tinggi kharismanya. Kyai mempunyai posisi yang absolut, menentukan corak kepemimpinan dan perkembangan pondok pesantren. Dalam konteks komunitas kyai, mereka yang yunior (Kiai muda) harus menghormati Kiai yang tua (senior). Dalam tradisi pesantren, status Kiai juga sering kali dilihat dari faktor keturunan Kiai yang memiliki kharisma besar kelak keturunannya menduduki status sosial yang sama dengan dirinya. Namun demikian, di sisi lain adanya keikhlasan yang muncul dari seorang Kiai membawa efek munculnya pesantren sebagai suatu lembaga pendidikan yang selalu disegani dan tetap menarik tanpa dipengaruhi oleh waktu yang berkembang dan lingkungan yang mengitarinya. Dalam kondisinya yang lebih maju, kedudukan Kiai dalam pondok pesantren tetap sebagai tokoh utamanya. Sebagai pemimpin, Kiai adalah pemilik dan guru utama dan secara tidak berlebihan Kiai adalah "raja" 
dalam pesantren. Lebih jauh pengaruh Kiai tidak hanya di lingkungan pesantrennya tetapi juga menyebar ke berbagai pelosok wilayah di luar pesantrennya.

Kuatnya pengaruh dari Kiai tentunya tidak lepas dari pola jaringan yang terbentuk di kalangan Kiai. Mengacu pada hasil penelitian Proyek Pengembangan Penelitian pada Perguruan Tinggi Agama Islam Direktorat Perguruan Tinggi Agama Islam Departemen Agama Republik Indonesia menyebutkan paling tidak ada 5 pola jaringan yang dikembangkan Kiai, yaitu:

1. Jaringan genealogis yang terbentuk melalui hubungan darah atau kekerabatan antara Kiai yang satu dengan Kiai lainnya. Bahkan tidak jarang sang Kiai mengambil menantu dari salah satu santrinya yang memiliki prestasi gemilang di pondok yang ia pimpin.

2. Jaringan ideologis yang terbentuk karena adanya persamaan kepentingan ideologis, baik yang bersifat pemahaman keagamaan (biasanya kalangan NU) maupun ideologi politik seperti PKB, PPP, PKU, PNU, dan sejenisnya.

3. Jaringan intelektual yang terbentuk melalui proses pembelajaran baik formal maupun nonformal antara guru (Kiai) dengan murid (santri)

4. Jaringan teologis. Jaringan ini terbentuk melalui kesamaan paham teologi yang diyakini dan dianut oleh para Kiai, yang pada umumnya di Jawa menyakini dan mengamalkan ajaran Asy'ariyah dan Maturudiyah atau yang lebih populer dengan 'Ahl al-Sunnah wa al-Jamā'ah'.

5. Jaringan spiritual yang terbentuk terutama melalui organisasi tarekat. Di Indonesia (khususnya Jawa) pada umumnya menganut tareqat Naqsabandiyah.

\section{Model-Model Keterlibatan Kiai dalam Kehidupan Politik}

Beberapa model keterlibatan Kiai dalam politik dapat dilihat melalui seberapa aktif Kiai bermain di ranah politik. Pertama, terlibat secara langsung sebagai praktisi dan aktor politik yang terjun sebagai pengurus dan aktivis partai politik tertentu. Terkadang Kiai dan keluarganya atau ustadz senior yang memiliki hubungan dengan Kiai yang terlibat secara langsung memberikan peluang politik yang lebih besar kepada elit pesantren untuk mencapai jabatan poilitik yang lebih baik. Posisi ini diharapkan dapat memberikan ruang politik untuk memperjuangkan kepentingan masyarakat dan kepentingan pesantren. Karena jabatan-jabatan politik turut menentukan kebijakan dan program-program pembangunan. Kasus terjun 
langsung dalam politik ini sebagaimana diperlihatkan oleh Nyai Ida Zainal di Pesantren Almunawwir Krapyak yang menjadi salah satu calon dalam pemilihan legislatif. Istri dari pemimpin Pesantren Al-munawwir yaitu Kiai Zainal Abidin tersebut menjadikan sang Kiai menjadi terlibat langsung dalam kegiatan politik.

Kedua, sebagai kekuatan pendukung partai politik tertentu dengan cara memberikan dukungan dibalik layar. Kiai menginisiasi berbagai kegitan keagamaan yang dimanfaatkan oleh partai politik untuk mensosialisasikan visi politiknya. Pada banyak kasus, Kiai memberikan persetujuan ketika pesantren dijadikan arena politik misalnya di wilayah kerja Kiai (baca : pesantren) digelar even-event keagamaan yang disponsori oleh kekuatan politik tertentu yang melibatkan masa umat Islam dalam jumlah yang banyak. Hal ini misalnya tercermin pada penyelenggaraan pertemuan Kiai yang dilaksanakan di sebuah hotel berbintang di Yogyakarta. Kegiatan bertajuk silaturrahmi itu ternyata disponsori oleh Politisi Partai Demokrat Anas Urbaningrum yang juga menantu Kiai Attabiq Ali Maksum, Pimpinan Yayasan Ali Maksum Krapyak.

Ketiga, sebagai legitimasi politik yang sering dimanifestasikan dalam bentuk restu politik pada partai atau tokoh politik tertentu yang tidak berasal dari lingkungan pesantren. Hal seperti ini bagi banyak praktisi politik dianggap penting. Sebab dalam sistem politik Indonesia yang ideologis dan tradisonal, legitimasi keagamaan merupakan sesuatu yang sangat dibutuhkan. Dan citra sebagai seorang muslim yang baik, sholeh, serta dekat dengan ulama turut menentukan elektibilitas seorang praktisi politik di hadapan pemilih muslim. Berkaitan dengan itu, Kiai menjadi tujuan kunjungan politisi, calon anggota legislatif, capres, atau komunitas partai politik tertentu yang sedang berkompetisi. Hal ini dilakukan sebagai proyek pemolesaan citra diri sebagai seorang muslim yang baik yang dekat dengan komunitas agama atau pesantren. Sebagai contoh pada pemilu Presiden Tahun 2004 semua calon presiden tercatat pernah berkunjung ke pesantren Al-Munawwir Krapyak untuk meminta restu dan doa dari Kiai di Pesantren Krapyak. Bahkan, Megawati yang saat itu sedang diterpa kontroversi kepemimpinan politik perempuan, juga mengunjungi Kiai dan pesantren dan hal ini dimanfaatkan dengan baik oleh tim suksesnya untuk membuktikan bahwa tidak semua Kiai NU menolak calon presiden perempuan. Demikian halnya pada pemilu presiden 2009, meskipun hanya Nyonya Mufida Yusuf Kalla, istri dari Capres Jusuf Kalla yang berkunjung ke Krapyak, namun di Televisi diperlihatkan safari politik dari Capres yang berkunjung atau 
sowan ke Kiai di pesantren lainnya di Pulau Jawa. Semuanya seakan berlomba paling cepat untuk mengunjungi dan mendapat restu dari Kiai.

Fakta di lapangan, kegagalan Nyai Ida Zainal dalam pertarungan menjadi Anggota DPRD Propinsi Yogyakarta melalui Partai Kebangkitan Nasional Ulama (PKNU) menggambarkan bahwa sikap maupun dukungan politik Kiai pada sebuah partai politik tertentu, tidak selalu paralel dengan dukungan masyarakat. Dan secara luas, legitimasi Kiai sebagai sumber moralitas politik menjadi tidak terlalu dihiraukan oleh masyarakat. Hal ini misalnya dapat dicermati pada pernyataan Kepala Dukuh Krapyak Kulon, Bapak Hunain bahwa masyarakat saat ini tidak lagi menjadikan sikap politik Kiai sebagai pedoman dalam memilih partai politik. Sebab para Kiai dinilai terlalu sibuk dengan aktifitas politiknya sendiri yang sering tidak memiliki hubungan langsung dengan kehidupan masyarakat.

\section{Memahami Motif Politik Kiai}

Proses-proses politik yang dilakukan oleh Kiai dalam politik didorong oleh motif politik yang beragam. Motif yang dimaksud didorong oleh kekuatan yang yang dimiliki oleh Kiai untuk terlibat dalam politik, baik yang disadari maupun tidak disadari untuk mencapai tujuan tertentu. Oleh sebab itu untuk menjelaskan motif keterlibatan Kiai dalam politik juga bukan sesuatu yang mudah. Di sini kita memasuki ranah perdebatan yang sensitif yakni berusaha menjelaskan berbagai alasan yang mendorong Kiai terlibat dalam politik. Satu hal yang sering kali tidak mau diakui oleh Kiai. Dibutuhkan suatu analisis yang lebih dalam dan cermat, karena keterlibatan Kiai dalam politik dipengaruhi berbagai faktor yang saling terkait, baik yang berasal dari kondisi-kondisi internal maupun tekanan eksternal. Berdasarkan data yang dikumpulkan melalui wawancara maupun observasi, maka setidaknya terdapat tiga motif atau alasan mengapa Kiai terlibat dalam politik.

\section{a. Doktrin Teologis}

Sebagai elit agama Islam yang memiliki basis keagamaan yang kuat dan mengajarkan ilmu-ilmu keislaman, maka basis argumentasi politik Kiai jelas bersandar pada pemahaman keagamaan yang kuat. Pemahaman tersebut disarikan dari penjelasan Al-Qur'an dan Sunnah serta paparan ulama-ulama terdahulu yang dijelaskan dalam berbagai kitab klasik (kitab kuning) yang sering dikaji dan sangat dipahami oleh Kiai. Umumnya Kiai memandang bahwa politik merupakan bagian dari pelaksaanaan ajaran Islam. Bernegara mempunyai 
koherensi dengan beragama yang direfleksikan dari pemikiran bahwa pendirian negara sesuai dengan Ijma ulama adalah hukumnya fardhu kifayah. Pandangan ini sejalan dengan kaidah Fiqh yang menyatakan man la yatimmuh al wajib illah bihi, fahuwa wajib (jika sesuatu kewajiban tidak dapat sempurna kecuali melalui alat atau sarana, maka alat atau sarana itu hukumnya wajib). Dalam logika ini bila menciptakan dan memelihara kemaslahatan adalah wajib, sedangkan alat untuk terciptanya kemaslahatan tersebut (salah satunya) adalah negara, maka hukum mendirikan negara juga wajib (fardu kifayah). Dalam teori politik Islam, pemahaman seperti ini lebih dikenal dengan paham akomodasionis yang memandang politik sebagai bagian dari ajaran agama yang tidak dapat dilepas-pisahkan (Syamsudin: 1993).

Konsekuensi dari berbagai pendapat tersebut di atas, dapat dikatakan bahwa mengelola negara dengan sebaik-baiknya sama hukumnya dengan mendirikan negara. Karena itu, ketika negara telah didirikan tetapi hanya menimbulkan mudharat, justru akan bertentangan dengan tujuan awal dibentuknya negara dalam Islam yakni membentuk masyarakat sejahtera di bawah ampunan Allah SWT, berpolitik merupakan salah satu kewajiban kifayah umat Islam untuk menegakkan nilai-nilai dan ajaran Islam.

\section{b. Mobilitas Struktural dan Kontekstualisasi Kiai}

Politik adalah suatu praktek tentang usaha untuk meraih kekuasaan politik. Sebab menguasai kekuasaan politik memberi ruang kepada kekuatan-kekuatan politik untuk merealisasikan visi, misi dan program-program politik yang akan dilaksanakan. Inilah kenyataan dalam kehidupan politik sejak demokrasi dicanangkan pertama kali dalam bentuknya yang paling sederhana. Kiai tentu menyadari fakta ini, sehingga keterlibatan Kiai dalam politik harus diletakkan dalam konteks mobilitas structural untuk memperjuangkan berbagai nilai, doktrin, semangat, aspirasi, dan kepentingan yang dianut oleh Kiai.

Keberhasilan meraih jabatan publik yang penting sebagai Presiden, Anggota DPR, Gubernur, Bupati atau Walikota diyakini mampu membuka ruang partisipasi bagi Kiai untuk berbuat lebih banyak. Justru bagi sebagai Kiai, ungkapan sebagian kalangan bahwa Kiai hanya layak bermain di wilayah kultural yang sekedar melakukan tugas-tugas kemasyarakatan merupakan pernyataan yang keliru dan ahistoris dan harus dicurigai. Hal ini misalnya diungkap oleh Kiai Miftahul Akhyar, seorang Kiai dari Jawa Timur dalam tulisannya di Republika, ia menyatakan : 
"Umat Islam, khususnya NU harus pandai menyaring pernyataan yang tampak manis tetapi sebenarnya akan memberangus agar NU dan Islam diluar pemerintahan dan dikuasai orang Islam tetapi tidak mengerti kemauan dan kebutuhan Islam. Justru pernyataan agar Kiai dan NU jangan terlibat politik merupakan usaha dari kelompok sekuler untuk melemahkan Islam"

Secara lebih luas keterlibatan Kiai dalam politik juga dapat dilihat sebagai upaya untuk memperluas peran dan sumberdaya yang dimiliki selama ini. Sebab selama beberapa dasawarsa -dibawah tekanan Orde Baru- Kiai hanya diperlakukan sebagai invisible actor yang berada di luar struktur kekuasaan politik. Padahal Kiai dengan jaringan dan sumber daya yang dimiliki menyimpan potensi dan pengaruh politik yang besar. Selama ini Kiai hanya dijadikan sebagai objek politik semata, ia sekedar alat politik bagi sebagian Partai Politik yang bisa digerakkan pada momentum pemilu. Namun setelah proses politik itu usai, Kiai dan pesantren sering dilupakan dari hingar bingar politik. Para Kiai menyadari hal tersebut dan mulai melakuan konsolidasi politik secara sistematis. Para Kiai yang tergabung dalam komunitas NU yang mendeklarasikan Partai Kebangkitan Bangsa (PKB) yang menandai momentum politik baru untuk memperluas wilayah dakwah, dari ranah kultural ke ranah struktural.

Politik menjadi sarana yang digunakan Kiai untuk unjuk peran maupun kontekstualisasi diri. Fenomena ini bisa dilihat sebagai bentuk respon politik terhadap dinamika eksternal. Apalagi sistem politik pasca reformasi membuka ruang politik yang lebih luas kepada kalangan Islam seperti Kiai untuk terlibat dalam usaha-usaha politik menyelesaikan beragam masalah kebangsaan. Maka keterlibatan dalam politik, bagi Kiai adalah panggilan sejarah untuk berbuat bagi kemajuan bangsa. Bila sebelumnya Kiai hanya diposisikan hanya untuk bermain di bidang kultural maka tiba saatnya bagi Kiai untuk melakukan kerja-kerja politik untuk kebaikan kehidupan berbangsa. Menurut Ahmad Patoni (2007), usaha para Kiai dan kalangan NU untuk mendirikan Partai Kebangkitan Bangsa (PKB) membuktikan bahwa Kiai mampu melihat efektifitas perjuangan moral pada level kekuasaan, hanya bisa diwujudkan melalui jalan politik. Melalui partai politik, Kiai meyakini mampu melakukan manuver taktis dalam mewujudkan kebijakan publik yang memihak kepada kepentingan masyarakat. Selain pertimbangan tersebut politik Kiai juga memiliki tujuan yang tidak kalah penting, yaitu memberikan benteng moralitas pada sebuah kehidupan politik yang sehat dan bermoral. Sebab perilaku para politikus diyakini sudah banyak yang menyimpang dari koridor moralitas-keberagamaan. Demi mencapai tujuan dan ambisi politiknya mereka rela melakukan apapun. Kehadiran Kiai diharapkan dapat memberikan 
sandaran dan perspektif moralitas, sehingga politik akan berjalan sesuai dengan rel kebenaran dan berdasarkan kepada landasan yang benar.

Selain soal mobilitas struktural dan kontekstualisasi diri yang perlu diwujudkan sesuai semangat zaman, Kiai sebagai elit agama pada dasarnya juga didesak oleh kekuatan politik eksternal untuk terlibat. Fenomena ini misalnya dapat kita saksikan pada Pemilu Presiden 2004, dimana PDIP perjuangan yang mencalonkan Megawati ingin menguasasi massa pesantren dengan menduetkan Ketua PDIP Megawati dengan Ketua PBNU Hasyim Muzadi. Pencalonan Hasyim Muzadi diharapkan dapat mewakili aspirasi umat Islam khususnya NU sekaligus mendorong dukungan politik dari kalangan Islam yang diakui jumlahnya sangat besar. Meskipun eksperimen politik ini tidak berhasil memenangkan pemilu, namun kasus ini menunjukkan bahwa alasan keterlibatan pesantren dalam politik juga karena desakan eksternal yang kuat. Apalagi bila desakan tersebut juga dibarengi dengan tawaran-tawaran ekonomi untuk kepentingan pembangunan pesantren.

\section{c. Kepentingan Pragmatis-Ekonomi.}

Liberalisasi dan kapitalisasi dunia pendidikan yang semakin masif di Indonesia akhirakhir ini, secara tidak terelakkan juga menimpa pesantren sebagai lembaga pendidikan tradisional yang dikelola secara swadaya oleh Kiai dan masyarakat. Biaya operasional pendidikan yang semakin tinggi berdampak langsung pada kondisi finansial pesantren. Dengan manajemen keuangan yang sangat sederhana, pesantren harus memperhatikan kemampuan pendanaan yang dimiliki. Dalam sejarah perkembangan pesantren, beberapa pesantren 'terpaksa' gulung tikar karena ketidakmampuan pembiayaan dalam menutupi biaya operasional pendidikan yang dijalankan. Pendapatan yang diperoleh dari iuran santri dan infak donatur yang tidak tetap, merupakan persoalan yang membutuhkan solusi yang tepat (Irwan Abdullah : 2008).

Situasi ini sering mendorong para Kiai dan pengelola pesantren untuk memikirkan cara-cara lain yang mudah dan efektif untuk memeroleh bantuan yang bisa digunakan untuk pembangunan pesantren. Di beberapa tempat pengelola pesantren berhasil memperoleh bantuan keuangan secara reguler dari pemerintah daerah atau pihak Kementerian Agama. Bahkan sebagian mendapat bantuan fisik berupa pembangunan infrastruktur pesantren. Bantuan-bantuan itu biasanya tidak gratis, karena pihak pemberi bantuan menuntut hal-hal tertentu. 
Selain menempuh cara tersebut, tidak jarang pesantren menempuh jalan pintas dengan melibatkan diri dalam politik kekuasaan yang dianggap cara yang cepat dan efektif untuk membangun jaringan donasi baru. Dengan pengaruh sosial dan politik yang kuat di masyarakat, pesantren dapat melakukan bargaining politik dengan para politisi yang memerlukan dukungan politik pesantren, dari sekedar dukungan moril dan pembentukan citra hingga mobilisasi suara rakyat dalam pemilu, pilpres atau pilkada. Meskipun secara terbuka pihak pengelola pesantren sering membantah melakukan bargaining politic dengan kompensasi ekonomi, namun fakta tentang bantuan yang diterima juga diakui. Di Pesantren Al-Munawwir misalnya, donasi dari kelompok politik banyak diterima pada era kepemimpinan KH. Ali Maksum yang juga seorang politisi NU. Demikian pula halnya pada kemimpinan KH. Zainal Abdidin Munawwir saat ini, pesantren juga menerima bantuan, meskipun diakui tidak terlalu banyak.

\section{Implikasi Politik Kiai : dari Pragmatisme Politik Menuju Resistensi Sosial.}

Pro dan kontra yang mengiringi keterlibatan Kiai dalam politik praktis pada dasarnya merupakan wujud ekspektasi umat terhadap posisi Kiai yang sangat terhormat. Sejak lama, umat Islam di Indonesia menempatkan Kiai sebagai sumber rujukan moralitas keagamaan. Para Kiai adalah panutan umat yang fatwa serta nasihatnya menjadi pegangan masyarakat dalam kehidupan. Bahkan menurut Zamakhsyari Dhofier sebagaimana dikutip Koirudin (2005; 144), peran Kiai merupakan faktor determinan kebijakan sosial, dan pengambilan keputusan-keputusan penting menyangkut keberhasilan kehidupan masyarakat.

Persoalan mengemuka ketika Kiai yang merupakan reverensi nilai-nilai keagamaan itu tertarik kedalam dunia politik praktis dengan berbagai alasan yang diyakininya. Di sinilah sebagian orang menilai sebagai bentuk penyimpangan terhadap peran sosial yang selama ini dimainkan Kiai. Apalagi keterlibatan Kiai dalam politik sering disertai aktivitas partisan sesuai tuntutan kepentingan politik yang terkadang tidak sejalan dengan logika masyarakat umum. Di sini, Kiai tidak dapat mempertahankan legitimasi keaagamaanya karena masyarakat telah meragukan otoritas dan ketulusan yang dimiliki. Yakni apakah pesantren sedang berbicara atas dasar kepentingan agama dan kepentingan umat atau atas dasar kepentingan partai politik atau politisi yang didukung pesantren.

Berbagai fenomena politik yang berkaitan dengan dukung mendukung politik oleh Kiai, menunjukkan bahwa aktivitas poltik Kiai ternyata memiliki implikasi yang sangat luas. 
Analisis terhadap hal ini bisa dimulai dari perdebatan doktrinal keagamaan tentang hubungan agama dan negara di Indonesia, hingga dampak-dampak material yang mungkin diperoleh oleh Kiai sehingga memperkuat kesimpulan tentang praktik prakmatis transaksional oleh Kiai. Dengan demikian Kiai terlibat politik bukanlah sebuah frase yang sederhana, tetapi memiliki implikasi yang luas dan mesti dianalisis secara hati-hati.

\section{a. Delegitimasi Terhadap Peran Kiai}

Banyak pesantren yang mengalami penurunan kualitas karena Kiai atau pimpinan pesantrennya lebih sibuk berpolitik. Dalam konteks penentangan atau penolakan ini, anjuran atau fatwa untuk memilih sebuah partai politik tertentu juga sering membuat umat terpecah dalam politik dukung mendukung yang tidak kondusif. Perpecahan suara yangsering diiringi dengan konflik-konflik sosial, membuktikan bahwa aktivitas politik praktis yang dilakoni Kiai lebih banyak menimbulkan mudharat.

Sementara itu, independensi Kiai yang selama ini menjadi rujukan utama dalam menjaga nilai-nilai dan moralitas masyarakat akan semakin sulit ditegakkan. Bahkan banyak Kiai yang masuk dalam lingkaran kekuasaan politik, secara sadar tunduk pada keputusankeputusan politik. Mereka harus turut menjalankan berbagai program dan

\section{b. Menguatnya Politik Pragmatisme-transaksional}

Implikasi lain dari keterlibatan Kiai dalam politik juga terlihat pada perubahan sarana fisik pesantren. Hal ini membenarkan penjelasan teori ekonomi politik deterministic yang memandang bahwa interaksi-interaksi politik selalu bermotif ekonomi (Stanyland, 2005:9). Kiai menjadikan pengaruh dan legitimasi sosial keagamaan yang dimiliki sebagai bahan tawar menawar dengan kelompok politik (interest group). Bantuan-bantuan material kerapkali kali datang ke pesantren sebagai buah dari konsensus politik yang dilakukan itu. Hal ini memunculkan rumor tentang politik uang yang sering diplesetkan menjadi hight cost politics.

Transaksi uang dengan suara dapat dilakukan dengan berbagai cara baik secara langsung maupun tidak langsung. Transasksi langsung mengandung pengertian, transaksi yang dilakukan oleh kelompok kepentingan langsung dengan memberikan uang dengan janji suara yang akan disalurkan melalui pesantren. Sedangkan transaksi tidak langsung dapat 
berupa benda atau apa saja yang dapat dipertukarkan dengan kepentingan Kiai, maupun "pembangunan pesantren". Alhasil posisi politik pesantren menjadi sangat pragmatis dan transaksional. Suatu praktik politik yang sangat tidak sehat dalam pembangunan demokrasi.

Pada pemilu 1999 dan Pemilu 2004, hampir semua pesantren NU termasuk Pesantren Al-Munawwir Krapyak mendukung penuh Partai Kebangkitan Bangsa. Dukungan tersebut mendatangkan banyak bantuan material. Pembangunan gedung pendidikan pesantren setinggi dua lantai yang menelan biaya miliran rupiah itu, diakui sebagian atas urungan Alwi Sihab, Ketua PKB 1999-2004. Ketua PKB dan Menkokesra di paroh pertama kabinet Susilo Bambang Yudhoyono itu juga menfasilitasi berbagai bantuan yang berasal dari para donatur di Timur Tengah. Disini terjadi perkawinan kepentingan, antara kelompok kepentingan (interest group) seperti partai politik dengan kepentingan Kiai dan pesantren sebagai kelompok sasaran (target group). Adanya perkawinan kepentingan tersebut menurut Koirudin (2005:105) memunculkan konsekuensi logis terjadinya pertukaran, lazimnya di pasar menggunakan uang sebagai alat transasksinya dan sebagai target group maka Kiai tidak mau lagi dibodohi interest group yang biasanya memerlukan pesantren pada momentum politik pemilu atau pilkada semata, dan setelah pemilu berakhir langsung dilupakan.

Politik kompensasi ekonomi ini menarik untuk diamati karena di satu sisi bermanfaat untuk melanjutkan pembangunan berbagai sarana dan prasarana pesantren, yang juga berarti menciptakan sumber pendanaan alternatif bagi kepentingan keuangan pesantren. Tetapi pada sisi yang lain menyeret pesantren pada pusaran politik pragmatis-transasional yang tidak sehat dan membahayakan, karena selalu mengkondisikan politik dengan uang. Terjadilah apa yang disebut "kapitalisasi pesantren" dalam transaki-transaksi politik dewasa ini. Suatu hal yang sangat menghawatirkan, sebab akan merusak integritas moral, legitimasi dan eksisitensi pesantren itu sendiri. Serta secara luas akan melemahkan posisi pesantren sebagai kekuatan civil society yang diharapkan mampu berhadapan vis a vis dengan kekuasaan.

\section{c. Resistensi Masyarakat Terhadap Kiai}

Secara tradisional masyarakat memandang Kiai sebagai sumber legitimasi moral. Kiai adalah panutan dan pembimbing umat dan sebagai sumber moral dan panutan umat maka Kiai diharapkan mampu menjadi teladan dalam mempraktekkan Islam ke dalam perilaku sehari-hari. Oleh karena itu Kiai harus menjaga diri dari hal-hal yang bisa merusak kewibawaan dan integritas, semisal keterlibatan Kiai dalam politik praktis. Memang tidak 
selamanya politik praktis sebagai "barang kotor", akan tetapi pemahaman masyarakat umum telah menempatkan politik sebagai media persaingan perebutan kekuasaan. Para Kiai misalnya akan menerima imbas dari persepsi umum ini. Konsekuensinya, predikat uswah hasanah Kiai tentu akan tercerabut legitimasi sosialnya. Petuah, nasihat maupun fatwa-fatwa yang dikeluarkan oleh Kiai akan dibaca dalam konteks politik. Sejauh ini ada beberapa bentuk resistensi masyarakat terhadap keterlibatan politik Kiai. Pertama, masyarakat menilai Kiai yang terlalu politis akan tercerabut dari fungsi-fungsinya sebagai panutan ajaran Islam. Dapat dilihat dari keengganan orang tua yang kritis menolak memasukkan anaknya ke dalam pesantren yang terlalu terlibat politik (Patoni, 2007).

Kedua, resistensi yang paling nyata tentu adalah pembangkangan politik yang dilakukan oleh masyarakat untuk tidak memilih partai yang didukung secara khusus oleh Kiai. Hal ini tentu menarik karena kontradiktif dengan dengan temuan Bolland (1982) bahwa masyarakat muslim tradisioal selalu mendukung sikap politik yang dianut oleh tokoh agama. Mungkin fenomena pesantren dan politik yang terjadi di Pesantren Al-Munawwir Krapyak dapat membantu menjelaskan bahwa saat ini sudah terjadi pergeseran sikap politik pemilih muslim, dari tipologi ideologis dan kharismatis ke sikap politik yang lebih rasional. Seiring demokratisasi dan perkembangan pendidikan, masyarakat semakin mampu membedakan sikap Kiai sebagai sikap keagamaan yang patut dicontoh, ditaati dan disuritauladani. Serta sikap Kiai yang sebetulnya adalah murni politik kepentingan yang tidak berkaitan dengan ajaran keagamaan sehingga tidak mesti ditaati.

\section{Kesimpulan}

Kajian ini menunjukkan bahwa keterlibatan Kiai di ranah politik yang semakin marak akhir-akhir ini, secara nyata telah menimbulkan berbagai implikasi yang cukup signifikan. Pertama, bahwa keterlibatan Kiai dalam politik secara nyata telah mendeligitmasi peran Kiai sebagai otoritas moral dan reverensi keagamaan. Banyak Kiai yang pengaruhnya berkurang karena Kiai atau pimpinan pesantrennya lebih sibuk berpolitik. Kondisi ini membuat masyarakat memandang Kiai tidak lagi objektif dalam sikap-sikap politiknya, karena cenderung menguntungkan kelompok politik tertentu sehingga terjadi delegetimasi peran pesantren. Kedua, Kiai telah turut mengukuhkan politik pragmatis-transasional, karena pesantren telah menjadikan politik sebagai ajang untuk mempertukarkan dukungan politik dengan konpensasi-konpensasi materi yang diterima. Bias politik Kiai ini tentu akan semakin menjauhkan Kiai dari masyarakat. Setidaknya hal ini mulai terasa belakangan ini, ketika 
masyarakat mulai menyoroti sikap politik pesantren yang dianggap hanya merusak independensi Kiai dan memecah umat kedalam politik partisan. Ketiga, terjadi resistensi masyarakat atas sikap politik Kiai. Hal ini secara nyata dapat disaksikan dalam sikap politik masyarakat yang seakan-akan membangkang terhadap pilihan politik yang diambil oleh Kiai. Seiring demokratisasi dan perkembangan pendidikan, masyarakat semakin mampu membedakan sikap Kiai sebagai sikap keagamaan yang patut dicontoh, ditaati dan diteladani. Serta sikap Kiai yang sebetulnya adalah murni politik kepentingan yang tidak berkaitan dengan ajaran keagamaan sehingga tidak mesti ditaati.

Disini terlihat bahwa Kiai perlu hati-hati dalam menentukan sikap politiknya. Sebab keterlibatan politik Kiai memiliki dampak yang tidak sebanding dengan manfaat yang diperoleh. Apalagi bila kesibukan politik telah melalaikan Kiai maupun pengelola pesantren dari urusan pendidikan di pesantren. Mungkin di masa depan Kiai perlu mempertimbangkan untuk melakukan revitalisasi peran politik yang lebih sesuai dengan semangat zaman dan keinginan masyarakat yang sudah semakin rasional. Sebab politik Kiai pada dasarnya bukan politik kekuasaan tetapi politik kerakyatan yang begerak pada ranah kultural.

\section{DAFTAR PUSTAKA}

Abdullah, Irwan, ddk. 2008. Agama, Pendidikan Islam dan Tanggung Jawab Sosial Pesantren, Yogyakarta: Sekolah Pascasarjana UGM bekerjasama Pustaka Pelajar.

Bolland, BJ. 1982. The Struggle of Islam in Modern Indonesia, The Hague: Martinus Nijhoff. Efendi, Bachtiar. 1996. Islam dan Negara, Jakarta; Paramadina.

Darban, Ahmad Adaby. 1987. Rifa'iyah: Gerakan Sosial Keagamaan di Pedesaan Jawa Tengah Tahun 1850 - 1982. Yogyakarta: Program Pascasarjana UGM

Deliarnov. 2003. Ekonomi Politik, Jakarta: Airlangga.

Dhovier, Zamakhsyari. 1990. Tradisi Pesantren, Studi tentang Pandangan Hidup Kiai. Jakarta : LP3S

Geertz, Clifford. 1989. Abangan, Santri, Priyayi dalam Masyarakat Jawa, Jakarta. Pustaka Jaya.

Horikoshi, Hiroko. 1987. Kiai dan Perubahan Sosial, Jakarta : LP3S. 
Iqbal, Muhammad. 2001. Fiqh Siyasah-Kontekstualisasi Doktrin Politik Islam, Jakarta; Graya Media Pratama.

Khoirudin. 2005. Politik Kiai, Yogyakarta : Averroes Press.

Marsh, David dan Gerry Stocker (ed). 2002. Theory and Metods in Political Science, New York : Palgraf, MacMillan.

Mansurnoor, Iik Arifin. 1990. Islam in Indonesian World. Ulama of Madura. Yogyakarta : Gadjah Mada University Press

Patoni, Ahmad. 2007. Peran Kiai Pesantren dalam Politik, Yogyakarta : Pustaka Pelajar.

Staniland, Martin. 2003. What is Political Economy? A Study of Social Theory and Underdevelopment, dalam Deliarnov. 2005. Ekonomi Politik, Jakarta; Airlangga.

Steenbrink, Karel A. 1994. Pesantren, Madrasah, Sekolah, Jakarta : LP3S.

Surbakti, Ramlan. 1984. Perbandingan Sistem Politik, Surabaya : Mecphiso Grafika.

Syamsuddin, Din. 1993, Usaha Pencarian Konsep Negara dalam Pemikiran Politik Islam, Jurnal

Turmudi, Endang. 2004, Kiai dan Perselingkuhan Kekuasaan, Yogyakarta : LKiS.

Yasmadi. 2002. Modernisasi Pesantren: Kritik Nurcholish Madjid terhadap Pendidikan Islam Tradisional. Jakarta: Ciputat Press. 